\title{
Gracious space: Library programming strategies towards immigrants as tools in the creation of social capital
}

\author{
Andreas Vårheim, University of Troms $\varnothing$
}

Accepted Author Manuscript (post-print)

of

Vårheim, A. (2011). Gracious space: Library programming strategies towards immigrants as tools in the creation of social capital. Library \& Information Science Research, 33(1), 12-18. doi:10.1016/j.lisr.2010.04.005

\begin{abstract}
Recent research on the generation of social trust and social capital gives public institutions prominent roles as instruments for creating social capital. Less is known about the specific institutions and actual mechanisms creating social capital. In this paper, public library programs directed towards immigrants are explored as one possible mechanism for social capital generation. The data are unstructured interviews with U.S. library directors on strategies for immigrant programs and the creation of social trust. The interviews are analyzed and discussed as a contribution to the knowledge on social capital formation. The relevant programming activities in the libraries studied, English as a second language classes, computer classes, and civics classes, attract the target immigrant populations and according to library directors interviewed these classes are successful in generating trust and social capital. People
\end{abstract}


come back to the library. Program design and program implementation have been carefully planned. Public libraries are promising arenas for generating social trust and follow-up studies of attitudes of immigrants participating in the programs are essential for creating more knowledge on the mechanisms creating trust and social capital, that is, for theory development, and for library practice. 


\section{Introduction}

Social capital is a strong predictor of individual health and human well-being; democracy and uncorrupt government are more prevalent in societies with high levels of social capital (Helliwell \& Putnam, 2004; Putnam, 2000; Rothstein \& Stolle, 2008). In recent research on the generation of social capital, public institutions are granted salient roles as instruments for creating social capital (Delhey \& Newton, 2005; Vårheim, Steinmo, \& Ide, 2008). Less is known about the specific institutions and actual mechanisms creating social capital.

\section{Problem statement}

Most immigrant populations have low social capital (Putnam, 2007). If the level of social capital can be increased by public policies, policies directed towards immigrants, starting from a low level, would have the greatest potential for success. Many public libraries offer activities in the form of English as a second language classes, computer classes, and civics classes for immigrants are offered in many public libraries. This makes library programs for immigrants interesting as one possible instrument for generating social trust where the mechanisms at work can be studied. To what extent is it likely that library programming towards immigrants contributes to social capital creation?

If it indeed turns out that the library directors can point to mechanisms by which social capital is created by and in the public library, further research investigating these mechanisms researching user attitudes and user behavior as participants in library programs would be warranted. With time, these results can be 
employed in library practice, in planning and running library activities, and in serving immigrant populations.

Social capital is defined as "features of social organization, such as trust, norms, and networks, that can improve the efficiency of society by facilitating coordinated action" (Putnam, 1993, p. 167). As with Putnam, Coleman (1990) and Fukuyama (1995) see trust as one core component of social capital. Trusting attitudes towards most people, towards people in general, generalized trust, is a crucial property defining social capital (Uslaner, 2002), while particularized trust means trust in only those known by the individual, and can be specified to a specific domain (Hardin, 2006). Social networks are another important part of social capital, but networks can consist of within-group relations leading to particularized trust and societal fragmentation. Generalized trust is one aspect of bridging social capital, while particularized trust corresponds with bonding social capital (Putnam, 2000). Bridging social capital is characterized by wider networks and many weak ties. Bonding social capital, on the other hand, is associated with more closed networks and strong ties between members. In most contexts, bridging social capital, is described as having positive effects for collective as well as for individual development. However, there is an interesting connection between the two forms of social capital, which means that the safety of within-group bonding relationships can lead to the risk taking necessary for out-group bridging relationships. This is discussed below.

Social capital is associated with almost any positive societal development. It has health benefits, it is good for democracy and political institutions, economic growth, community development, and helps in fighting crime, drug abuse, and teenage pregnancies (Granovetter, 1985; Hutchinson \& Vidal, 2004; Knack \& Keefer, 1997; Putnam, 1993, 2000, 2004; Wakefield \& Poland, 2005). With such a record for 
social capital, the roots of social capital and how it can be generated, become central questions for research.

Public libraries can be understood as places of discovery for the individual. These processes of discovery can either be directed inwards towards own background and culture, or the world outside. This means that library programming for immigrants can serve both processes of group identity formation (creating particularized trust and bonding social capital) and processes of integration (creating generalized trust and bridging social capital). There are Spanish language collections and English as a second language classes (ESL classes) offered to the same patrons. For example, English language classes can produce a whole range of social capital effects ranging from trust in others and learning leading to self-efficacy generating possibilities for further education and finding a better paid job.

\section{Literature review}

Two main theoretical perspectives exist regarding the genesis of social capital. One perspective, the societal perspective, locates the formation of social capital in civil society; in voluntary associations and in informal person to person interaction (Putnam, 2000). The second strand of research, the institutional perspective, finds that social capital is created by political institutions (Fukuyama, 1995; Levi, 1997, 1998), first and foremost by universal and impartial public service institutions that meet their clients on street level, social service institutions (Kumlin \& Rothstein, 2005), the police and the judicial system (Rothstein \& Stolle, 2008), and public libraries (Vårheim, 2007; Vårheim et al., 2008).

The findings are in many ways inconclusive. Both perspectives are ridden with the problem of specifying the direction of causality (Delhey \& Newton, 2005). Is it 
voluntary associations or institutions that create social capital, or is it even the other way around? Is it the case in societies with high social capital, flourishing voluntary associations, and/or where public institutions and public services are universalistic and impartial, that these phenomena themselves have been created and are maintained by preexisting social capital? In other words, that social capital is not generated by associations or institutions, but that it is the historically high level of social capital that makes these associations and institutions viable in the first place.

This crucial and yet unresolved question within social capital research has lead to studies investigating whether social capital and generalized trust in fact are created as a result of contact between societal groups and/or by meeting fair public institutions. Basically, bridging social capital or generalized trust means trust in others, in unknown people and diverse others. It could be argued that among marginalized groups, where trust in general is low, for example, within racial and ethnic minorities, the effect of contact with other ethnic groups/majority groups would be greater and more easily detected than among majority groups. The study of contact with others and contact intervention among ethnic minorities is therefore perhaps one fruitful way to find out more about what creates trust, and how trust is created. Most research on race and ethnicity in relation to social capital tells a depressing story of low and declining trust within these groups (Alesina \& La Ferrara, 2000, 2002; Coffe \& Geys, 2006; Costa \& Kahn, 2003; Delhey \& Newton, 2005). Also, interaction between different racial and ethnic groups does not seem to have significant effects on generalized trust. However, informal contact between white neighbors increases trust (Marschall \& Stolle, 2004, 2006).

More optimistically, Uslaner (2006) found that what really matters regarding trust and ethnicity is the composition of neighborhoods. Segregated neighborhoods 
mean increased distrust between groups, while mixed neighborhoods can enhance trust. Putnam (2007) describes how bonding within newly arrived immigrant groups to the United States historically gave them a platform for developing inter-group contact and bridging social capital over time. Nannestad, Svendsen \& Svendsen (2008) find that among immigrants to Denmark levels of bonding social capital and bridging social capital is positively correlated. These findings can mean that intragroup contact between immigrants should be encouraged, especially in the early stages of life in the new country. This runs contrary to earlier research in the Danish case that find no correlation between intra-group associational memberships and generalized trust among second generation immigrants (Togeby, 2004). Further evidence from Denmark suggests that public libraries are most successful in promoting integration when providing universal services rather than focusing upon the immigrants cultures of origin (Elbeshausen \& Skov, 2004).

Hooghe (2007) discards the ideals of high trust societies and trust generation. Since diversity is negatively correlated to generalized trust, the only way out of this dilemma is to abandon the ideal of high trust unless a policy of ethnic homogeneity is pursued. Therefore, societies need to work without high trust levels because high trust societies depend on circumstances that are no longer politically feasible. This calls for political institutions capable of regulating peoples' daily lives in a manner acceptable to diverse societal groups also in low trust environments. However, Hooghe seems to forget that what he is proposing is a stable institutional environment that by its ability and legitimacy can be expected to produce conditions conducive of increasing levels of trust. This is what Kumlin \& Rothstein suggest in the paper "Minorities and Mistrust: The Cushioning Impact of Social Contacts and Institutional Fairness" (2008). Fair, universalistic public institutions treating everyone equally make all 
classes more trusting towards these institutions, and ultimately more trusting towards each other and towards the unknown other, the argument goes. They also argue that social contact with diverse others makes people more trusting towards people in general. In line with the theoretical reasoning at the outset of the paper, particularly ethnic minorities benefit from social contact and impartial institutions:

"Informal social interaction and institutional fairness are not only beneficial for general trust levels. More than this, in the Swedish context they seem to be particularly beneficial for minorities. Therefore, at the highest levels of informal interaction and fairness, trust differences between minority and majority are not be found.” (Kumlin \& Rothstein, 2008, p. 22).

This means that increased ethnic diversity does not necessarily lead to permanent low social trust, and low social capital societies. Universalistic public institutions that people trust, function in a fair and efficient manner, and it is the fact that they work that make people trust. Regarding informal social contact the picture is more complex. Contact happens in all kinds of contexts, between all kinds of people, lord and peasant, rich and poor, priest and parishioner, employer and employee, teacher and student, and actually very few contexts can be said to be particularly well suited for creating trust as long as contacts follow vertical power lines as opposed to horizontal contacts. Therefore, without specifying the conditions for social contacts producing social trust, it becomes doubtful that contact actually produces trust. A more elaborate model of the contact-generating-trust process needs to be developed. 
Within socio-psychological research the conditions for contact to create trust have been studied. For trust enhancing contact between diverse people to take place many conditions that are not easily satisfied, exist: "equal group status within the situation, common goals; inter-group cooperation; and the support of authorities, law, or custom" (Pettigrew, 1998, p. 65). Very few arenas can be expected to fulfill all these conditions, but some venues are closer than others, for example public parks, bus stops, shopping malls, public schools, and public libraries. Parks and bus stops, of course, are the most open arenas in that they mostly are outside. It is even so questionable whether they are considered safe places by most people, and what do people talk about when they meet in these arenas; probably the weather. Public schools are universalistic institutions, but every strata of society does not go there, and the range of age cohorts that are in school is very compressed. While considering the limitations on the openness of even open spaces, it is interesting to observe that public libraries come out as places fulfilling most of Pettigrew's criteria for contact creating trust.

Universalistic public institutions create trust in that their clients are treated fairly, and that the clients get what they expect. Public libraries belong to this category of institutions, but they also provide an institutional setting for informal contact on an equal basis between clients in that everybody is free to use the library, all social classes, men and women, and all age groups. This makes libraries fairly unique arenas in that they combine the possibility of creating trust both as a fair institution and as an arena for informal contact where it is likely that people at least some of the time talk about document related topics rather than how terribly hot it is outside or how freezing cold it is inside. In investigating the contribution of public libraries as arenas for contact between people both the societal and institutionalist 
perspectives on the generation of social capital are central to the analysis. This means that the generation of social capital both have societal and institutional elements in the context of public libraries. The two perspectives complement each other.

Contrary to many other public institutions, public libraries very much function in the same universal manner, at least across western type societies. In selecting U.S. libraries as the empirical focus, the rainmaker effect of other universalistic institutions is minimized in that the United States has comparatively few universal service welfare state institutions, but still has advanced public libraries. This means that it could be easier to detect the effect of libraries on social trust in the United States than in for example western Europe.

In line with the general focus on diverse groups within social capital research one specific set of library activities, activities directed at underrepresented user groups, is studied. These groups are mostly racial and ethnic minority groups. If public libraries are able to attract ethnically diverse groups to, for example, English as a second language classes, the library has made it possible for diverse groups to meet others in the same situation, further, to meet librarians, other library users, and the public library institution. Even if libraries are unable to recruit participants in classes as individual future library users, enrolling them in language courses in the first place creates contacts and bridges between diverse people, and possibly create some measure of trust, even if small. It can be the making of this minimal trust that breeds more trust in the lives of immigrants, documented or undocumented. In depicting the logic of these processes, one will know more about if or how public libraries create generalized trust.

\section{Library programming and social capital}


As universal service institutions public libraries in the literature have been described as producers of social capital through offering information services to everybody, and by being a meeting place where diverse people meet and are treated as equals and with respect (Vårheim, 2007). Similarly, Caidi (2006) points to the role of libraries as supporting institutions for community building and individual capacity and empowerment by investing "in people and communities (rather than in books and technologies)" (209). Overall (2009) stresses the need for developing the cultural competence of librarians as one key factor for meeting the needs of immigrants and under-served population groups. In this paper, focus is on one set of library activities, activities to bring library services to groups that under-use them. Except for the rich and men, these groups are mostly marginalized minority groups. The building of a branch library in an underprivileged neighborhood is in itself a prime example of community building with possible social capital effects (see, e. g., (Putnam, Feldstein, \& Cohen, 2003)). From, for example, Boulder Public Library, Boulder, Colorado, one knows, that immigrant groups are recruited by librarians actively canvassing the neighborhoods to offer their services, for example, language classes (Vårheim et al., 2008). In expanding the number of cases and in trying to learn more about the strategies by which public libraries recruit diverse patrons, and how the services offered are seen as creating social trust, this paper explores the possible social capital effects of public library programs towards minorities seen from the viewpoint of the library organization.

The simple model is that participation in library programs creates contact with the library, and that this contact creates trust. A meta-analysis of experimental research shows that contact, and especially in the form of language, creates cooperation beyond the predictions of the theory of self-interested rational action 
(Sally, 1995). All the libraries visited, had programs for immigrants. What are the strategies for attracting immigrant user groups? What are the initiatives and activities that have impact and make people participate? These questions can be answered in part by library strategy data. However, a fuller understanding will emerge when user data is studied.

\section{Procedures}

It is known that it is very likely that libraries create trust on the macro-level (Vårheim et al., 2008); one also knows a little bit about how it is created on the microlevel; (Cox, Swinbourne, Pip, \& Laing, 2000; Vårheim, 2007; Vårheim et al., 2008), but more in-depth material documenting the actual mechanisms and processes generating generalized trust is needed. "Process tracing" is a well established case study methodology providing knowledge of causal mechanisms and making analytical generalization possible (George \& McKeown, 1985; Hall, 2003; Steinmo, 2008). Process tracing is specifically designed for inferring causality by identifying causal mechanisms. Through the study of the process (-es) at hand, the causal mechanisms that link the independent variables with the dependent variable, a causal path, a causal chain, a causal story can be identified.

Considering that little is known about the mechanisms and processes whereby social trust is generated in general and even less in public libraries, in tracing these processes, as a first approximation, the impressions of a few U.S. library directors are analyzed. The directors have been selected because they have been thought of as the executives of library policies in their libraries, and because they are expected to have the most comprehensive overview of their library's policies and being able to express 
the contents of policies and their rationale in a wider meaning. In research with a distinct explorative flavor, interview data from directors would be a starting point in tracing the processes whereby trust could be generated in the library programming.

The findings on the strategies and implementation of programs for immigrants and their perceived effects on social trust, are opening up the institutional mechanisms for trust creation, and provide valuable knowledge that can be a beginning for studying the trust creating process from a user perspective. That is, designing the questions needed for investigating how the library activities studied create trust and what the mechanisms are. In this exploratory research, finding relevant questions is as important as any other finding.

Among racial and ethnic minority groups in the United States underusing library services, the Hispanic population is by far the biggest. 21 million people in the United States speak little or no English. This is 50 percent more than a decade ago. A new study from the American Library Association on the demographics of public libraries serving non-English speakers in areas that have more than a certain proportion of "linguistically isolated" households as defined by the U.S. Census 2000 $(A L A, 2008)^{i i}$, finds that in 78 percent of these libraries Spanish is the most supported minority language regarding services and programs. Asian languages are prioritized as number two with 29 percent, while Indo-European languages fall far behind.

In line with the fact that Spanish is the biggest and most supported minority language, cases have been chosen to reflect this while at the same time including communities of varying sizes. However, some smaller communities with a Hispanic population below average have been included for increasing the variance on the dependent variable. Most of the library systems are located in the west, but also systems on the east coast have been studied. Table 1. provides an overview of the 
cases regarding central population characteristics, race and ethnicity, percentage below a certain level of English proficiency, percentage of first generation immigrants and how many of them came from Latin America, and the percentage of immigrants that entered the United States 2000-2007.

[Table 1. here]

Table 2. shows the percentages of linguistically isolated families, their first languages and the proportion of people speaking English less than very well in the library system areas studied.

[Table 2. here]

Unstructured interviews were conducted with eleven library directors, and in two big city library systems, two directors of library services and one city branch head, in total fourteen people in twelve public library systems.iii The interviews were carried out by the author in June, 2007, except for one that was done in July, 2008.

\section{Analysis - programming strategies}

Key-components of the libraries' strategies towards immigrants can be easily identified in their mission statements and in their policies. More difficult tasks are to sort out the rationale for the mission statements, the link between mission statements and library policies, and finally the connection from policies to policy instruments in the form of library programs and activities. 
The library's mission

A public library's mission statement can be empty phrases or it can be a foundation for the library's real work, for its goals, strategies, and policies, and their implementation. The mission statements of the libraries at hand vary in their level of abstraction, but most stress the importance of the universality of access to information, and that it is the mission of the library to provide information for entertainment and lifelong learning, to provide a place for social interaction, to be a community center and a gathering place, to strengthen and build community. The mission statement of one of the library systems encompasses most of the elements: "It is our mission to inform, empower, inspire, and entertain through service and resources that respect individuals and ideas, foster discovery, and build community." (Library system E, 2009).

How are these big words put into practice? How are the strategies intended to work as instruments for building trust in the library, for creating trust among users, and eventually perhaps into generating trust in most people? Is there any variation in strategies among libraries in doing this? Do their policies differ in the objectives for programming towards immigrants, in the actual ways of reaching out to immigrants and to groups of non-patrons?

\section{Policy: From mission to policy instruments}

Studying work for recruiting new library users among underrepresented groups is one way of operationalizing the public libraries' mission of providing universal access to information, being for all, and for building community. When interviewing library directors about the rationale for reaching out to immigrants, nuances and differences in emphasis on the mission and goals of public libraries 
appear. ${ }^{\text {iv }}$ The cleavages pertain to the arguments for bringing all segments of the population in.

On the one hand, some directors perceive public libraries as institutions building community and generating trust by being forums for engaging everyone in the community, and this is the library's operating mission. Here are some examples of statements in the interviews indicating this:

"the library is the living room of the community", "the library is a stable factor in the community", the library connects with the community", " the library is an important part of the community infrastructure", "the library is a healing force when community is in conflict", "Mexicans are distrustful of government, and of government attempts at building trust. The library creates trust by being an open community forum, and when we deliver on our promises: trust is our currency; trust in the library and voluntary organizations produce trust in the community." "The public library is a special place in the community where every part of the community intersect. It is the only place that isn't segregated. It brakes down barriers, build understanding, and awareness". "The library finds ways for interaction with all groups".

On the other hand, one group of library directors underscore that the main goal for the public library is providing access to information as building blocks of democracy based on citizens' constitutional rights. Community building and the possible increase in individual well being that might follow 
from this and especially for disadvantaged people are but secondary considerations. Meetings in the library between patrons, formally or informally, are not primarily seen as social events and community building exercises, but opportunities for exposing people to diverse ideas and creating civic discourse (Library director VIII). Emphasis is put on public libraries as foundational concepts, providing equal access to information in nonjudgmental places, encouraging ideas, diversity, and impartiality (Library director VIII; Library director IX), rather than community building.

The two different viewpoints among library directors might be labeled an activity perspective versus a constitutional perspective. This difference in policy emphasis regarding the role of the public library immediately comes up when discussing the question how libraries can contribute in creating social trust.

Both "activists" and "constitutionalists" find that patrons' trust in the public library as an institution is the basis for the activities and basic functioning of libraries. Among constitutionalists "trust begins with the library seen as a neutral ground, there is no bias, it is trust about the institution, the library is a trustworthy institution" (Library director IX). It is seen as an impartial institution because "it is open to everyone regardless of socio-economic status. When [patrons] are able to follow general rules of protocol they are treated with respect. Their information needs are handled professionally without prejudice" (Library director IX). Reaching out to societal groups, the inclusion of more meeting space in new library buildings, and expanding the role of the library as a meeting place are institutional components added to fulfill the original idea of the library as an impartial provider of information for everyone. For example, immigrants need to learn how the library institution 
works, an why it can be trusted. Therefore, for libraries to function as beacons of democracy gaps in literacy between social groups need to be filled. By being a space opening up for differences in literacy needs and promoting an informed citizenry, the public library can fulfill its vocation as an instrument for the freedom of ideas and democracy (Library director VIII).

Activists say they share the information paradigm of neutrality and universality. However, they stress the importance of interaction between groups in the library more. It is this interaction between patrons and the basic interaction with the library in the form of interaction with librarians, who are perceived as helpful and without prejudice, and that patrons are trusted with material for free, that make libraries tic as trust creating institutions: "Libraries are publicly funded, they are symbolic places for all, they symbolize trust, people leave their children here; nonjudgmental interaction occurs between groups, people see each other in nonconfrontational contexts; trust comes when people in the community see that you try" (Library director X).

The library is described as having a special position in the community. Here people from different groups intersect: "It is the only place not segregated" (Library director X). It helps breaking down barriers as public schools do, but in the library people from different generations also meet. Related to this, the library has a unique role in creating civic discourse. People are exposed to different ideas, it is safe to express one's genuine opinions, also uncomfortable opinions. Libraries are good places for starting building bridges between different groups. Immigration, health care, and transportation issues can discussed in the library (Library director IX).

Activists and constitutionalists differ in their arguments for what is the main purpose of public libraries. Among activists social integration is more pronounced in 
the interviews, while among constitutionalists citizens' rights and literacy is emphasized. Both find that trust in the library institution is basic for libraries fulfilling their mission. It is from this trust they think public libraries can promote integration and democracy. Further, the two groups agree that trust is built by library activities. However, one would expect that activities or policy tools would vary between integrative measures in activist libraries and literacy measures in constitutionalist libraries. Do they? Are the the two library "ideologies" reflected in what libraries do?

\section{Policy instruments}

Regarding the policy instruments studied, the interviews do not reveal any significant differences between activist and constitutionalist libraries. English as a Second Language classes (ESL classes), computer skills classes, and civics classes are three main types of library activities or policy instruments directed at underrepresented immigrant groups. These activities are offered in most of the libraries studied, not necessarily all three activities in all libraries, but very few have only one of the programs ongoing. The reasoning behind policies differs, but policy instruments do not. The programs are perceived as instruments of both literacy and social integration.

But the question remains, how is it done, how do public libraries make their universalistic services truly universal, that is, make the services available for as many strata of the population as possible? For example, how do they recruit immigrants as participants in programs, and how are the programs organized, and how do they operate? 
Recruiting immigrants

A variety of activities are used in the libraries studied for attracting immigrants as library users. Broadly speaking, the interviewees distinguish recruitment efforts according to whether it is new or ongoing programs that are to be promoted. Also new library branches are established with the objective of recruiting new user groups, and these big interventions of course need elaborate marketing efforts. It is claimed that recruitment efforts need to be more intensive with some immigrant groups than others, especially Hispanics are difficult to recruit as library users.

From experience, active recruitment drives are needed to get new library branches and programs going, library directors say. Multiple approaches have been used. In several of the library systems new library branches have been established in areas with high densities of Hispanic immigrants. In this case, the building of new branch libraries is recruitment by itself, and it is perhaps the most important recruitment activity of immigrants to new branches in the areas where they live ((Putnam et al., 2003), Library director II). Recruitment, in the first instance, means making the library branch visible in the community. Some spectacular event as a motorcade through the neighborhoods is one example of this, "people came" (Library director I). Library participation and promotion at local festivals is another strategy. More everyday marketing in communities is distributing fliers to trailer homes, translation of advertising into Spanish, handing out in school information brochures for bringing home to parents. The process of disseminating information about the library involves close cooperation with voluntary organizations, for example, contacts made through cooperation with the Catholic Church has been important in one 
community (Library director II), and cooperation with social agencies in another: "We tap into their clients" (Library director I).

However, word of mouth is what the library directors think is the most important marketing instrument for recruiting immigrants that for the most part have little trust in the library and government institutions: "When the programs are well established, word of mouth is the way we do it" (Library director III). This means that library services themselves is the most important marketing tool.

Organizing library programs for immigrants

In addition to ESL classes, computer classes, and civics courses, the libraries in question help with access to GED ("General Educational Diploma”) classes that give access to university level education, and they have extensive services for children: story-times (where also parents (mostly mothers) meet), early childhood libraries, teen space, family space, services for day care centers and schools, are some examples. Bookmobiles serve neighborhoods without branches. The libraries have bilingual personnel, and Spanish speaking outreach librarians. There is also a policy for hiring librarians with Hispanic ethnicity. There is some evidence that this increases usage from this ethnic group (Library director VI).

Among the libraries in the sample, two models of organizing ESL classes are in use, either the library run the classes themselves or they are, in two cases, organized through a partner organization in the local community that runs the actual course in another venue than the library. The classes are offered on different skill levels. Each class has a small number of students, and is often taught on a one-to-one basis. Teachers are hired by the library and are often volunteers. Many are retired teachers. Computer classes teach basic computer skills with a hands-on approach. 
Civics classes teach the syllabus for the U.S. citizenship exam and are also taught in small groups. The library classes are free, people can come as they like, they are without any exams, the teacher student ratio is high, in many cases $1: 1$. The idea is lowering the threshold for attendance to make the courses attendable for the people most in need, with the lowest level of English literacy. Many of the students are people that have dropped out of other language learning programs, but who seem to cope with the approach offered by the public libraries.

\section{Discussion}

Surprisingly, the data do not show differences to speak of in library outreach activities between the libraries studied. The arguments for policy instruments vary, but policy implementation does not. This means that it should be possible to find other drivers behind this fact of uniform policies. One important observation is the similarities among potential new library clients or users. Big Spanish speaking minorities is a trait common to most of the library systems studied. Therefore, user demographics could be the driver of library activities and policies. When understanding libraries as universalistic institutions both in their general services and in their programs, providing basically the same services to everybody, the leeway for discretionary and organizational impact on policies is smaller.

The strong universalistic aspect of the public library institution regarding the way library services are provided, and across communities and nations, means that it could be these institutional values that are expressed in what libraries dov ${ }^{\mathrm{v}}$. That library services are planned, organized, and implemented according to the presence of area 
demographic groups, can thus be an expression of the strong institutionalized universalistic values inherent in the library institution, that is, the same universal values are expressed most places, but applied to the context of library districts. In contrast, studies of what is often thought of as another universalist institution, public schools, report a negative effect regarding trust among Latino immigrant high school students. Attending ESL classes in high school stigmatize and erode trust rather than open up new avenues for these students (Ream \& Stanton-Salazar, 2007, 69). In public libraries ESL classes are not an alternative to "ordinary classes", they are “ordinary classes”. Participation in library ESL classes can help immigrant parents involve themselves more in the everyday school activity of the children.

Compared to the institutional values of the library, shifting activist and constitutionalist policies or even maybe shifting conservative and liberal local government political regimes become surface phenomena. One of the library directors interviewed described the public library as a "gracious space", a welcoming and big enough place for everyone to come, and where they by extension take part in the creation of a more "informed citizenry" (Library director VIII). The concept of gracious space nicely refines the universalistic and institutional values that public libraries expound that transcend activist and constitutionalist policy positions. Public libraries seem to be parts of the communicative infrastructure that is beyond policy regimes and political bickering.

This means that the effects of library activities on social trust are derived from the application of universal library values to a specific social context. Outreach activities such as ESL classes and computer classes respond to the social context of American libraries today; this is their application of the institutionalized universal 
values of the public library. Increased migration worldwide makes the American experience increasingly relevant outside the United States.

\section{Conclusion}

The exploratory interviews and analysis made in this paper indicate mechanisms by which the public library can contribute in creating social trust, in particular for Hispanic immigrants to the United States. The strategies for outreach to immigrants seem to contain the same programs and activities independently of the prevailing library policy regime in the library district, that is, independently of whether the library director is activist or constitutionalist. Constitutionalist directors put more emphasis on universal access to information and literacy, while activist directors see libraries more as social places, places for social integration. However, in the implementation of these visions of the library into actual programs and activities both activists and constitutionalists seem to offer very similar programs for immigrants. In this way the universalistic aspect of the public library institution, public libraries are for everyone, seems to transcend political ideologies. The principle of universality implies that user groups underrepresented in the library are selected as targets for outreach activity. Demography and the need of the underrepresented, not political ideologies, drive the initiatives. Libraries are thought of as building trust through their institutionalized universalistic policies. Even if immigrants are very distrusting of government institutions, it is probable that public libraries are among the least distrusted and therefore has a comparative advantage in creating trust. At the same time libraries offer useful skills in the form of English literacy, computer skills, and civics skills, for free, and in a flexible manner. Also the 
elaborate designs of the library programs studied indicate that the success rate could be high.

The fact that immigrants come to the classes in the first place is a sign of trust. The contact with the library institution and meeting others in the same circumstances probably will enhance this institutional trust in the public library as well as trust in fellow program participants.

This may spill over onto most library users, and may in the long run turn into generalized trust and bridging social capital. This paper finds that the public libraries studied had strategies for building trust and social capital, and with the strong focus on relevant programs it is likely that the public libraries studied are contributors in the creation of social trust. There are clear indications that public library programming ran as described in the paper, are social trust creating library services. It is demonstrated that public libraries through their programming towards immigrants are employing policy tools that probably generate generalized trust and social capital among their newly recruited patrons. In a follow-up study, the attitudes of immigrant participants in ESL classes, computer classes, and civics education, is studied in detail for describing the trust creating mechanisms. This is another step towards resolving the present impasse of social capital research on how social trust and social capital are produced. Is it institutions or social interaction that create trust, or maybe the two factors interact so that they together generate trust? This is an important question for the well being of individuals and societies, and for library practice.

\section{Notes}


i An approach closely related to the study of public libraries' contribution to social capital is based on the theory of information grounds focusing on the outcomes

ii Linguistically isolated households are households in which no household member age 14 or older report speaking English at least "very well".

iii This study is based upon official library documents (budgets and plans) and interviews with library directors. The next study conducted will be gathering and analyzing data on and from participants in library programs.

iv The library directors were asked open ended questions on the strategies and activities geared towards immigrants, about library patrons, the library programming, about library funding and organization, the political climate in the area, and about whether they thought that libraries can/and how libraries can contribute in creating social trust.

v See Steinmo,Thelen, \& Longstreth (1992) and Steinmo (2008) for elaborations on institutional theory and historical institutionalism.

\section{References}

ALA. (2008). Serving non-English speakers in U.S. public libraries: 2007 Analysis of Library Demographics, Services and Programs. American Library Association. Retrieved from

http://www.ala.org/ala/aboutala/offices/olos/nonenglishspeakers/index.cfm.

Alesina, A., \& La Ferrara, E. (2000). Participation in heterogeneous communities.

Quarterly Journal of Economics, 115(3), 847-904.

Alesina, A., \& La Ferrara, E. (2002). Who trusts others? Journal of Public

Economics, 85(2), 207-234.

Caidi, N. (2006). Building "civilisational competence": a new role for libraries? Journal of Documentation, 62(2), 194-212.

Coffe, H., \& Geys, B. (2006). Community heterogeneity: A burden for the creation of social capital? Social Science Quarterly, 87(5), 1053-1072.

Coleman, J. S. (1990). Foundations of social theory. Cambridge, Mass.: Belknap Press. 
Costa, D. L., \& Kahn, M. E. (2003). Understanding the American decline in social capital, 1952-1998. Kyklos, 56(1), 17-46.

Cox, E., Swinbourne, K., Pip, C., \& Laing, S. (2000). A safe place to go: Libraries and social capital (p. 53). Sydney: University of Technology, Sydney, and the State Library of New South Wales. Retrieved from http://www.sl.nsw.gov.au/pls/publications/pdf/safe_place.pdf.

Delhey, J., \& Newton, K. (2005). Predicting cross-national levels of social trust: Global pattern or Nordic exceptionalism? European Sociological Review, 21(4), 311-327.

Durrance, J. C., \& Fisher, K. E. (2003). Determining how libraries and librarians help. Library Trends, 51(4), 305-334.

Elbeshausen, H., \& Skov, P. (2004). Public libraries in a multicultural space: A case study of integration processes in local communities. New Library World, 105(3/4), 131-141.

Fisher, K. E., Durrance, J. C., \& Hinton, M. B. (2004). Information grounds and the use of need-based services by immigrants in Queens, New York: A contextbased, outcome evaluation approach. Journal of the American Society for Information Science and Technology, 55(8), 754-766.

Fukuyama, F. (1995). Trust: social virtues and the creation of prosperity. New York: Free Press.

George, A. L., \& McKeown, T. J. (1985). Case Studies and Theories of Organizational Decision Making. Advances in Information Processing in Organizations, 2, 21-58.

Granovetter, M. S. (1985). Economic action and social structure: The problem of embeddedness. American Journal of Sociology, 91(3), 481-510. 
Hall, P. A. (2003). Aligning Ontology and Methodology in Comparative Research. In J. Mahoney \& D. Rueschemeyer (Eds.), Comparative historical analysis in the social sciences (pp. 373-406). Cambridge: Cambridge University Press.

Hardin, R. (2006). Trust. Cambridge: Polity.

Helliwell, J. F., \& Putnam, R. D. (2004). The social context of well-being. Philosophical Transactions of the Royal Society of London Series BBiological Sciences, 359(1449), 1435-1446.

Hooghe, M. (2007). Social Capital and Diversity Generalized Trust, Social Cohesion and Regimes of Diversity. Canadian Journal of Political Science/Revue canadienne de science politique, 40(03), 709-732.

Hutchinson, J., \& Vidal, A. C. (2004). Using social capital to help integrate planning theory, research, and practice. Journal of the American Planning Association, 70(2), 142-192.

Knack, S., \& Keefer, P. (1997). Does social capital have an economic payoff? A cross-country investigation. The Quarterly Journal of Economics, 112(4), 1251-1288.

Kumlin, S., \& Rothstein, B. (2005). Making and breaking social capital: The impact of welfare-state institutions. Comparative Political Studies, 38(4), 339-365.

Kumlin, S., \& Rothstein, B. (2008). Minorities and Mistrust: The Cushioning Impact of Social Contacts and Institutional Fairness. QoG Working Paper Series (p. 33). Working Paper, Göteborg, Sweden: The Quality of Government Institute, Department of Political Science, Göteborg University.

Levi, M. (1997). Consent, dissent, and patriotism. Political economy of institutions and decisions. Cambridge: Cambridge University Press. 
Levi, M. (1998). A state of trust. In V. A. Braithwaite \& M. Levi (Eds.), Trust and governance (pp. 77-101). New York: Russell Sage Foundation.

Library system E. (2009). PPLD Vision, Mission, Philosophy \& Guiding Principles. Retrieved from http://library.ppld.org/AboutYourLibrary/admin/Policies/mission.asp.

Marschall, M. J., \& Stolle, D. (2004). Race and the city: Neighborhood context and the development of generalized trust. Political Behavior, 26(2), 125-153.

Marschall, M. J., \& Stolle, D. (2006). Seeing or Living Diversity: Contact with Diverse Others and the Development of Generalized Trust. Canadian Political Science Association Annual Meeting. Retrieved from http://www.cpsaacsp.ca/template_e.cfm?folder=conference\&page_name=agm-papers2005.htm\#j.

Nannestad, P., Svendsen, G. L. H., \& Svendsen, G. T. (2008). Bridge over troubled water: migration and social capital. Journal of Ethnic and Migration Studies, 34(4), 607-631.

Overall, P. M. (2009). Cultural Competence: A Conceptual Framework for Library and Information Science Professionals. The Library Quarterly, 79(2), 175204.

Pettigrew, T. F. (1998). Intergroup contact theory. Annual Review of Psychology, 49, $65-85$.

Putnam, R. D. (1993). Making democracy work: Civic traditions in modern Italy. Princeton, N.J.: Princeton University Press.

Putnam, R. D. (2000). Bowling alone: The collapse and revival of American community. New York: Simon \& Schuster. 
Putnam, R. D. (2004). Health by association? Social capital, social theory, and the political economy of public health - Commentary: 'Health by association': Some comments. International Journal of Epidemiology, 33(4), 667-671.

Putnam, R. D. (2007). E Pluribus Unum: Diversity and community in the twenty-first century. The 2006 Johan Skytte Prize Lecture. Scandinavian Political Studies, $30(2), 137-174$.

Putnam, R. D., Feldstein, L. M., \& Cohen, D. (2003). Better together: Restoring the American community. New York: Simon \& Schuster.

Rothstein, B., \& Stolle, D. (2008). The state and social capital - An institutional theory of generalized trust. Comparative Politics, 40(4), 441-459.

Sally, D. (1995). Conversation and cooperation in social dilemmas: a meta-analysis of experiments from 1958 to 1992. Rationality and Society, 7(1), 58-92.

Steinmo, S. (2008). Historical Institutionalism. In M. Keating \& D. Della Porta (Eds.), Approaches and Methodologies in the Social Sciences: a pluralist perspective (pp. 118-138). Cambridge: Cambridge University Press.

Steinmo, S., Thelen, K., \& Longstreth, F. (1992). Structuring Politics: Historical Institutionalism in Comparative Analysis. Cambridge: Cambridge University Press.

Togeby, L. (2004). It depends... How organisational participation affects political participation and social trust among second-generation immigrants in Denmark. Journal of Ethnic Migration Studies, 30(3), 509-528.

Uslaner, E. M. (2002). The moral foundations of trust. New York: Cambridge University Press.

Uslaner, E. M. (2006). Does diversity drive down trust? FEEM Working Paper No. 69. Retrieved from http://ssrn.com/abstract=903051. 
Vårheim, A. (2007). Social capital and public libraries: The need for research. Library \& Information Science Research, 29(3), 416-428.

Vårheim, A., Steinmo, S., \& Ide, E. (2008). Do Libraries matter? Public libraries and the creation of social capital. Journal of Documentation, 64(6), 877-892.

Wakefield, S. E. L., \& Poland, B. (2005). Family, friend or foe? Critical reflections on the relevance and role of social capital in health promotion and community development. Social Science \& Medicine, 60(12), 2819-32. 


\begin{tabular}{|l|l|l|l|l|l|l|l|}
\hline $\begin{array}{c}\text { Library } \\
\text { System }\end{array}$ & $\begin{array}{l}\text { Populati } \\
\text { on }\end{array}$ & White & Hispanic & Other & $\begin{array}{c}\text { Foreig } \\
\text { n born }\end{array}$ & $\begin{array}{c}\text { Latin } \\
\text { America } \\
\mathbf{n}\end{array}$ & $\begin{array}{c}\text { Entered } \\
\mathbf{2 0 0 0} \\
\mathbf{2 0 0 7}\end{array}$ \\
\hline A & 576,842 & 50.5 & $\begin{array}{l}34.2 \\
(27.3)^{\mathrm{a}}\end{array}$ & 15.3 & 18.3 & 69.9 & 32.4 \\
\hline B & 235,328 & 69.0 & $\begin{array}{l}27.5 \\
(22.8)\end{array}$ & 3.5 & 9.8 & NA & 30.0 \\
\hline C & 85,841 & 81.4 & $11.3(6.1)$ & 7.3 & 3.1 & NA & 20.0 \\
\hline D & $5,982,452$ & 35.1 & $27.4(3.2)$ & 37.5 & 32.3 & 54.1 & 21.3 \\
\hline E & 578,779 & 74.2 & $12.9(8.3)$ & 12.9 & 7.8 & 40.1 & 28.3 \\
\hline F & 14,872 & 90.6 & $6.5(4.4)$ & 2.9 & 10.9 & 39.6 & 5.0 \\
\hline G & 173,308 & 84.0 & $10.0(7.4)$ & 6.0 & 6.4 & NA & 37.4 \\
\hline H & 30,230 & 76.9 & $6.1(2.1)$ & 17.0 & 20.1 & 21.7 & 11.3 \\
\hline I & 152,216 & 56.6 & 38.8 & 4.6 & 3.4 & NA & 39.3 \\
\hline J & $2,263,858$ & 31.0 & $26.2(3.2)$ & 42.8 & 48.3 & 49.1 & 20.0 \\
\hline K & 182,610 & 67.3 & $21.5(16.3)$ & 11.2 & 11.3 & 58.9 & 31.5 \\
\hline L & 65,163 & 48.1 & $46.4(14.1)$ & 5.5 & 12.7 & NA & 45.8 \\
\hline USA & $298,757,3$ & 66.3 & $14.7(9.4)$ & 19.0 & 12.5 & 14.7 & 53.4 \\
\hline & 10 & & & & & & \\
\hline
\end{tabular}

Table 1. Ethnic groups, foreign born, foreign born from Latin America, and U.S. entry in the selected library system areas and the United States. Percentages.

${ }^{a}$ Percentage of total population from Mexico.

Sources: U.S. Census Bureau, 2005-2007 American Community Survey 3-Year Estimates, Data Profiles, Selected Population Profiles, Detailed Tables.

For library systems $F$ and $H$ :

U.S. Census Bureau, Census 2000 Summary File 1 (SF 1) 100-Percent Data, DP

1. Profile of General Demographic Characteristics. 


\begin{tabular}{|l|l|l|l|l|l|l|}
\hline $\begin{array}{c}\text { Library } \\
\text { System }\end{array}$ & $\begin{array}{c}\text { All } \\
\text { household } \\
\text { s }\end{array}$ & Spanish & $\begin{array}{c}\text { Other Indo- } \\
\text { European }\end{array}$ & Asian & Others & $\begin{array}{c}\text { Englis } \\
\text { h level }\end{array}$ \\
\hline A & 8.4 & 35.3 & 15.7 & 37.4 & 19.7 & 15.4 \\
\hline B & 5.0 & 28.4 & 10.0 & 26.0 & 0.0 & 8.6 \\
\hline C & 0.4 & 4.8 & 0.0 & 5.8 & 0.0 & NA \\
\hline D & 15.5 & 32.9 & 29.4 & 43.7 & 22.3 & 19.5 \\
\hline E & 2.4 & 21.2 & 7.1 & 12.1 & 8.8 & 4.4 \\
\hline F & 2.0 & 25.0 & 4.4 & 7.4 & 0.0 & 4.3 \\
\hline G & 2.4 & 21.4 & 4.1 & 23.9 & 28.0 & 3.7 \\
\hline H & 4.6 & 27.8 & 13.9 & 21.7 & 0.0 & 6.8 \\
\hline I & 2.1 & 10.9 & 1.2 & 14.9 & NA & 3.8 \\
\hline J & 19.7 & 35.0 & 28.7 & 43.7 & 20.5 & 28.9 \\
\hline K & 7.7 & 37.2 & 17.0 & 31.0 & 12.1 & 8.3 \\
\hline L & 7.4 & 21.3 & 1.7 & 24.0 & 9.0 & 13.2 \\
\hline USA & 4.8 & 27.6 & 16.5 & 27,8 & 16.3 & 8.6 \\
\hline
\end{tabular}

Table 2. Linguistically isolated, primary languages, and level of English. Percentages.

"Percentage that speaks English less than "very well"

Sources: U.S. Census Bureau, 2005-2007 American Community Survey 3-Year Estimates, Data Profiles, Selected Population Profiles, Detailed Tables; S1602.

Linguistic Isolation.

For library systems $F$ and $H$ :

U.S. Census Bureau, Census 2000 Summary File 3 (SF 3) Sample Data, DP-2. Profile of Selected Social Characteristics; P20. Household Language by Linguistic Isolation [14] - Universe: Households. 